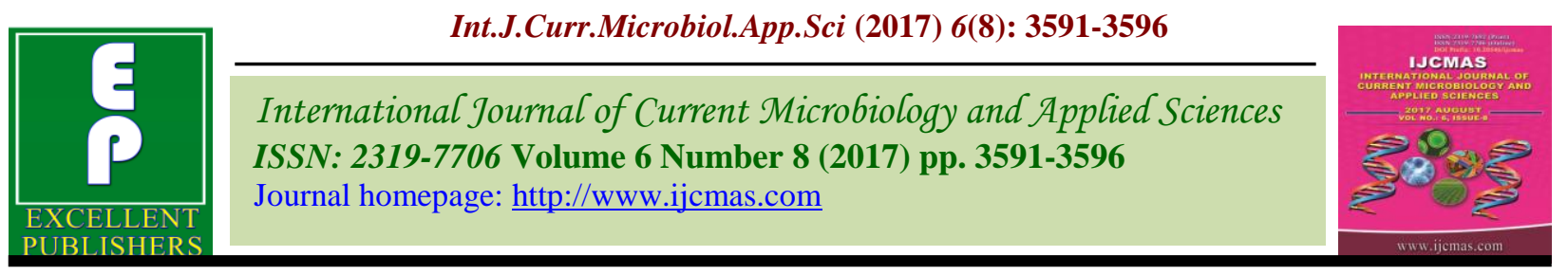

Original Research Article https://doi.org/10.20546/ijcmas.2017.608.431

\title{
Problems Perceived by the Women Workers under MGNREGA in Jaipur District of Rajasthan, India
}

\author{
Annu Devi Gora*, Madhuri Joshi and Radhika Tanwer
}

SKN College of agriculture Jobner, Jaipur, India

*Corresponding author

\begin{tabular}{|c|c|}
\hline & B S T R A T \\
\hline Keywords & \multirow{4}{*}{$\begin{array}{l}\text { The present study was conducted in Jaipur District of Rajasthan, to find out } \\
\text { the problems perceived by women workers in MGNREGA. For this, one } \\
\text { hundred twenty MNREGA women workers were selected and information } \\
\text { was collected with the help of structured Interview schedule and data was } \\
\text { analysed with the appropriate statistical tools as; mean percent score; } \\
\text { ranking and result were drawn from it. It was found that women workers } \\
\text { were perceived problems Children left uncared" (personal and family), } \\
\text { "Delay in issuing a job card" (operational) and "Lack of drinking water } \\
\text { facility" at worksite. }\end{array}$} \\
\hline $\begin{array}{l}\text { MGNREGA and } \\
\text { Women workers. }\end{array}$ & \\
\hline & \\
\hline $\begin{array}{l}\text { Accepted: } \\
\text { 27 June } 2017 \\
\text { Available Online: } \\
\text { 10 August } 2017\end{array}$ & \\
\hline
\end{tabular}

\section{Introduction}

Mahatma Gandhi National Rural Employment Guarantee Act (MGNREGA) is the largest ever public programme conceived and grounded in the human history. It is the most powerful initiative ever undertaken for the transformation of rural livelihoods. It goes beyond poverty alleviation and recognizes employment as a legal right. It creates the right to work. It is demand-driven. It has the potential to provide a 'big push' in Indian regions of distress. It is designed as a safety net to reduce migration by rural poor households in the lean period through a hundred days of guaranteed unskilled manual labour provided when demanded, at minimum wage on works focused on water conservation, land development and drought proofing. The unique feature of this programme is that it is the first ever law internationally, that guarantees wage employment at an unprecedented scale. The Act aims at enhancing livelihood security of households in rural areas of the country. The primary objective of this Act is, to enhance livelihood security in rural areas by providing at least 100 days of guaranteed wage employment in a financial year to every BPL (Below Poverty Line) and APL (Above Poverty Line) household whose adult members volunteer to do unskilled manual work.

In every society women play a very crucial role. Where women have been given chance, they have not only excelled in all areas, but also have played an important role in the development of country as a whole. They make a significant contribution to economic 
and social development, as citizen's worker and mothers. Success of any development effort depends on the effective participation of women in the development programme. In path of gaining benefits of any programme, constraints are the speed breakers which slow down the accessibility of individual towards achieving them.

Women are too much preoccupied with domestic chores that they are starkly ignorant about the outside world. They are not aware about income generating programmes which could help better in their socio-economic lot. Thus to strengthen the effectiveness of any programme, constraints in its success needs to be identified. An attempt has therefore been made to study the constraints being faced by the beneficiaries of MGNREGA.

\section{Materials and Methods}

The study was conducted in Dudu panchayat samiti in Jaipur district of Rajasthan. Dudu panchayat samiti consisted of 57 villages. Out of which 4 villages were selected on the basis of total active women workers. Four villages namely Habaspura, Hirnoda,Naraina and Mozamadad were selected for study.

From every selected village, a list of all workers registered in the master roll in MNREGA during last 2 years i.e. 2013-14 and 2014-15 was obtained from the Surpanch. From this list, 30 women workers benefitted through MGNREGA were selected randomly Thus a total of 120 respondents from four villages were selected for the investigation.

\section{Results and Discussion}

\section{Problems perceived by women workers in} MGNREGA

Problems perceived by the women workers towards MGNREGA programme were grouped in to three major categories viz., personal and family problems, operational problems and problems on worksite. The responses were recorded as most important, important and least important.

\section{Personal and family problems}

Results show that the most important problems faced by the women were "Children left uncared" (83.33 MPS) followed by "Domestic work neglected" (81.66 MPS).

This may be due to the reason that children were either left with the family members or were brought to the work site, where the mothers were busy with the work so the children were unattended.

The least important problems reported were "Non-cooperation from family members" (58.38 MPS) and "No extra work can be taken up due to fatigue and debility" (60.55 MPS). May be due to the fact that MGNREGA gives some earning to the family thus family members cooperate each other.

The findings of this study support the findings of Tiwari and Upadhyay (2012), Garg (2008).

\section{Operational problems}

The data reveal that the most important problems faced were "Delay in issuing job card" (79.44 MPS) and "Huge delay in work payment" (77.77 MPS) followed by "Wages not provided according to MGNREGA act" (76.66 MPS). It may be because of the lengthy official procedure.

Further mostly the earth works are taken up under MGNREGA so the measurement of the work is sometime not proper which causes delay in the payment. 
Table.1 Problems related to individual and family

\begin{tabular}{|c|c|c|c|c|c|c|c|}
\hline \multirow{2}{*}{$\begin{array}{l}\text { S. } \\
\text { No. }\end{array}$} & \multirow[t]{2}{*}{ Problems } & \multicolumn{6}{|c|}{ Mean percent score } \\
\hline & & $\begin{array}{l}\text { Habaspura } \\
\left(\mathbf{n}_{1}\right)\end{array}$ & $\begin{array}{l}\text { Hirnoda } \\
\left(\mathbf{n}_{2}\right)\end{array}$ & $\begin{array}{l}\text { Naraina } \\
\left(\mathbf{n}_{3}\right)\end{array}$ & $\begin{array}{l}\text { Mozamabad } \\
\left(\mathbf{n}_{4}\right)\end{array}$ & $\begin{array}{l}\text { Overall } \\
(\mathrm{N}=120)\end{array}$ & Rank \\
\hline 1 & $\begin{array}{l}\text { Too much workload } \\
\text { in family }\end{array}$ & 63.33 & 73.33 & 81.11 & 68.88 & 71.66 & III \\
\hline 2 & $\begin{array}{l}\text { Non-cooperation } \\
\text { from family } \\
\text { members }\end{array}$ & 64.44 & 75.55 & 41.11 & 46.66 & 58.38 & VI \\
\hline 3 & $\begin{array}{l}\text { Domestic work } \\
\text { neglected }\end{array}$ & 80.00 & 76.66 & 97.77 & 72.22 & 81.66 & II \\
\hline 4 & $\begin{array}{l}\text { No extra work can be } \\
\text { taken up due to } \\
\text { fatigue and debility }\end{array}$ & 67.77 & 64.44 & 57.77 & 52.22 & 60.55 & $\mathrm{~V}$ \\
\hline 5 & Children left uncared & 74.44 & 83.33 & 96.66 & 75.55 & 83.33 & I \\
\hline 6 & $\begin{array}{l}\text { Farm and cattle care } \\
\text { activities not } \\
\text { attended properly }\end{array}$ & 66.66 & 66.66 & 68.66 & 51.11 & 63.33 & IV \\
\hline
\end{tabular}

Table.2 Problems related to operation of the programme

\begin{tabular}{|c|c|c|c|c|c|c|c|}
\hline \multirow{2}{*}{$\begin{array}{l}\text { S. } \\
\text { No. }\end{array}$} & \multirow[b]{2}{*}{ Problems } & \multicolumn{6}{|c|}{ Mean Percent Score } \\
\hline & & $\begin{array}{l}\text { Habaspura } \\
\left(\mathbf{n}_{1}\right)\end{array}$ & $\begin{array}{l}\text { Hirnoda } \\
\left(\mathbf{n}_{2}\right)\end{array}$ & $\begin{array}{l}\text { Naraina } \\
\left(\mathbf{n}_{3}\right)\end{array}$ & $\begin{array}{l}\text { Mozamabad } \\
\left(\mathbf{n}_{4}\right)\end{array}$ & $\begin{array}{l}\text { Overall } \\
(N=120)\end{array}$ & Rank \\
\hline 1 & Delay in issuing a job card & 71.11 & 74.44 & 94.44 & 77.77 & 79.44 & I \\
\hline 2 & $\begin{array}{l}\text { Unemployment } \\
\text { allowances not provided in } \\
\text { case of delay in job. }\end{array}$ & 65.55 & 70.00 & 60.00 & 52.22 & 61.94 & VIII \\
\hline 3 & $\begin{array}{l}\text { Job card not hold by real } \\
\text { beneficiaries }\end{array}$ & 58.88 & 56.66 & 37.77 & 60.00 & 53.34 & $\mathrm{X}$ \\
\hline 4 & $\begin{array}{l}\text { Families below poverty } \\
\text { line not registered }\end{array}$ & 60.00 & 55.55 & 36.66 & 66.66 & 54.72 & IX \\
\hline 5 & $\begin{array}{l}\text { Unable to availed } 150 \\
\text { days of employment } \\
\text { according to the act. }\end{array}$ & 64.44 & 68.88 & 68.88 & 70.00 & 68.05 & $\mathrm{~V}$ \\
\hline 6 & $\begin{array}{l}\text { Wages not provided } \\
\text { according to MGNREGA } \\
\text { act }\end{array}$ & 70.00 & 74.44 & 58.55 & 76.66 & 76.66 & III \\
\hline 7 & $\begin{array}{l}\text { Huge delay in work } \\
\text { payment }\end{array}$ & 68.88 & 84.44 & 78.88 & 78.88 & 77.77 & II \\
\hline 8 & $\begin{array}{l}\text { Difference } \\
\text { in wage }\end{array}$ & 57.77 & 47.77 & 36.66 & 44.44 & 46.94 & XI \\
\hline 9 & $\begin{array}{l}\text { Improper measurement of } \\
\text { earth work }\end{array}$ & 61.11 & 67.77 & 65.55 & 70.05 & 66.11 & VI \\
\hline 10 & $\begin{array}{l}\text { Behaviour of mate is not } \\
\text { good. }\end{array}$ & 72.22 & 61.11 & 67.77 & 68.88 & 76.22 & IV \\
\hline 11 & $\begin{array}{l}\text { The measurement of work } \\
\text { is not proper }\end{array}$ & 66.66 & 71.11 & 69.25 & 53.33 & 64.44 & VII \\
\hline
\end{tabular}


Table.3 Problems related to worksite

S. Problems

No.

\section{Mean percent score}

Habaspura Hirnoda Naraina Mozamabad Overall Rank

$\left(\mathbf{n}_{1}\right)$

$\left(\mathbf{n}_{2}\right)$

$\left(\mathbf{n}_{3}\right)$

$\left(\mathbf{n}_{4}\right)$

$(\mathrm{N}=30)$

$1 \quad$ Lack of safe drinking water

67.77

66.66

73.11

68.11

73.38

I

63.33

61.33

71.11

62.22

52.22

62.22

IV

3 Ex-gratia payment not given after injury

$4 \quad$ No shade during rest period

65.55

81.11

72.22

72.22

53.33

V

5

No extra facilities are given to women

$6 \quad$ Long distance provided for work
$62.22 \quad 38.88$

54.44

57.77

68.88

64.44

67.77

63.33
$72.77 \quad$ II

$53.20 \quad$ VI

65.38

III

Fig.1 Problems related to worksite

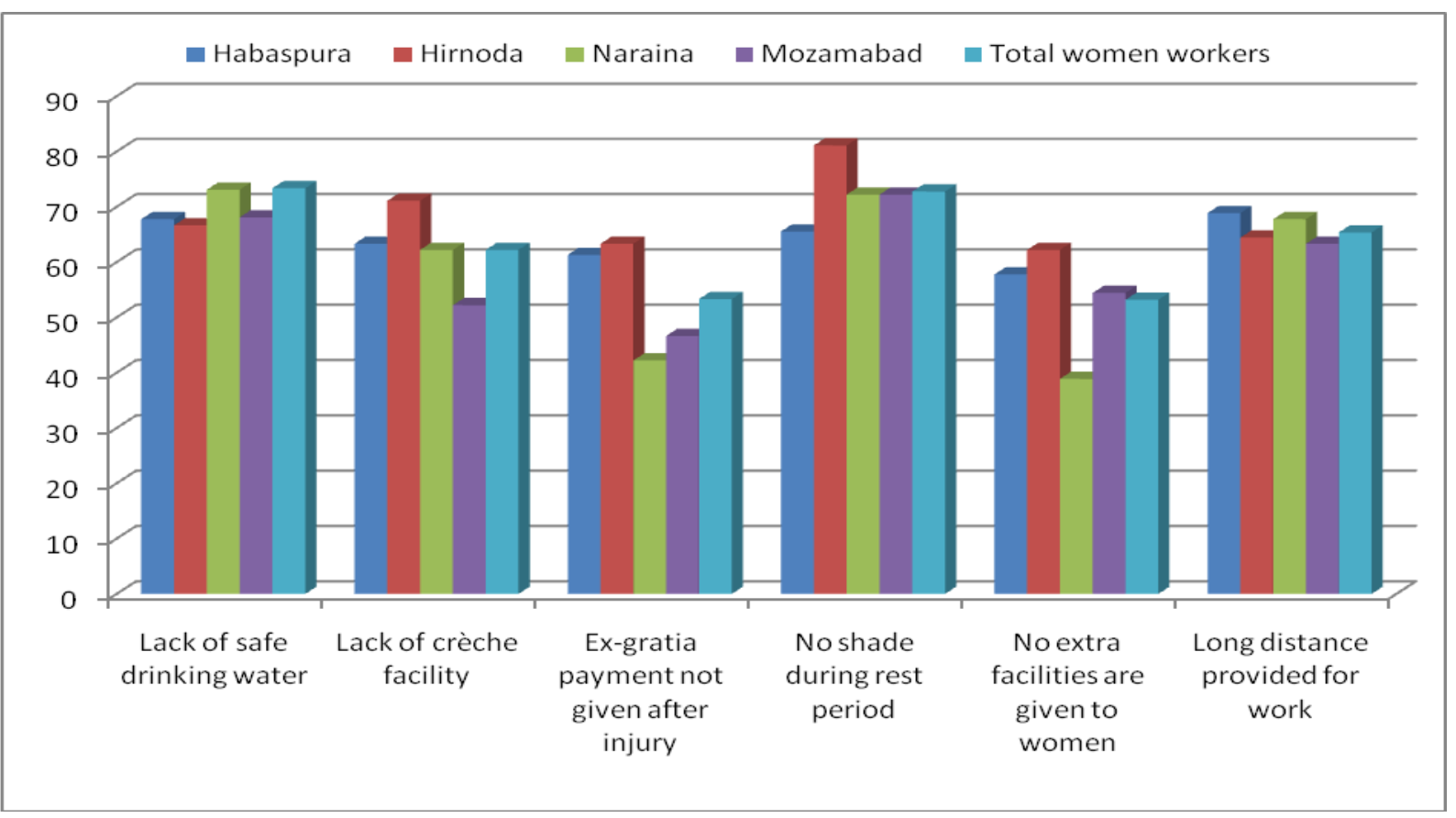


Fig.2 Problems related to individual and family

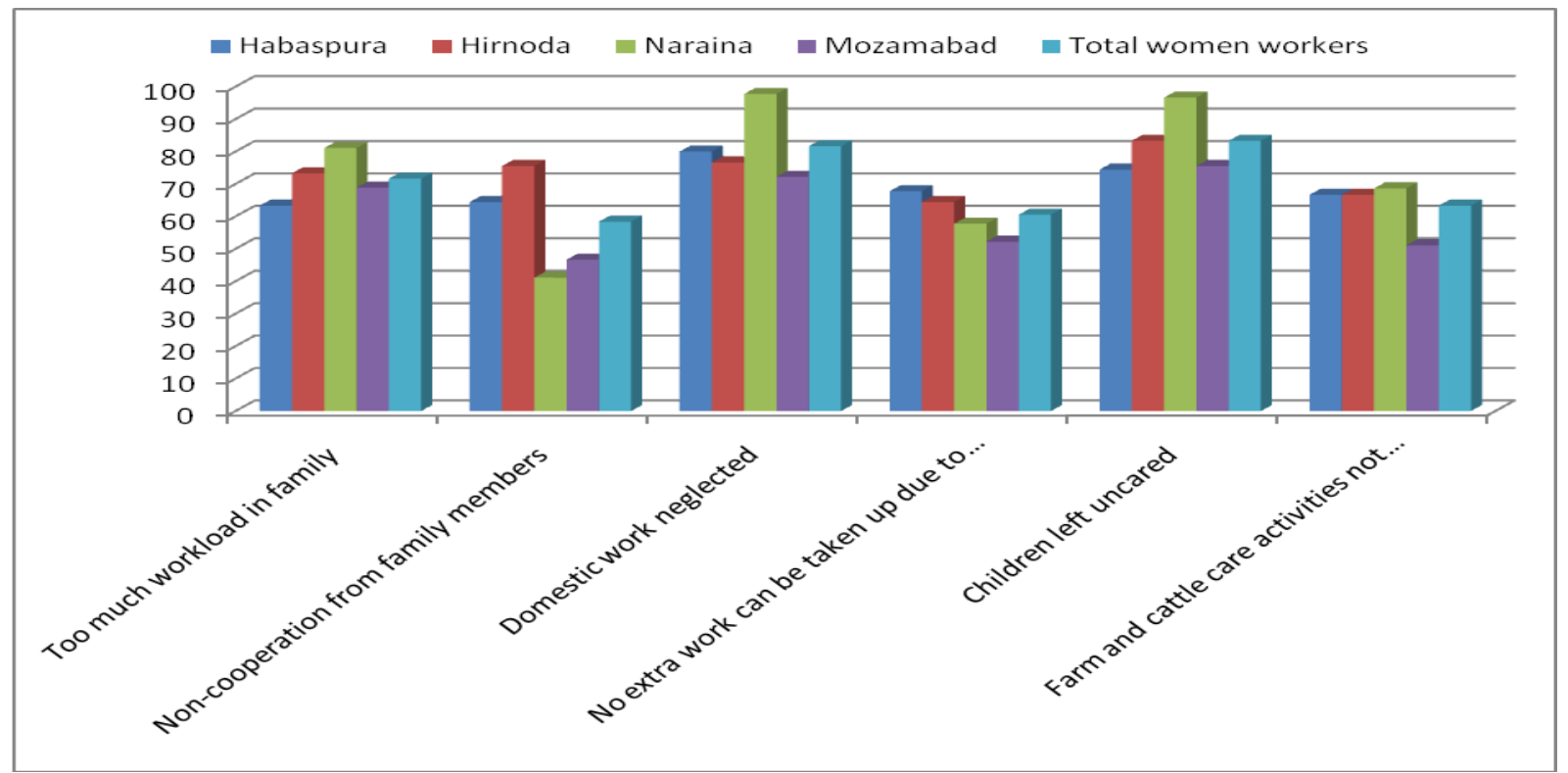

Fig.3 Problems related to operation of programme

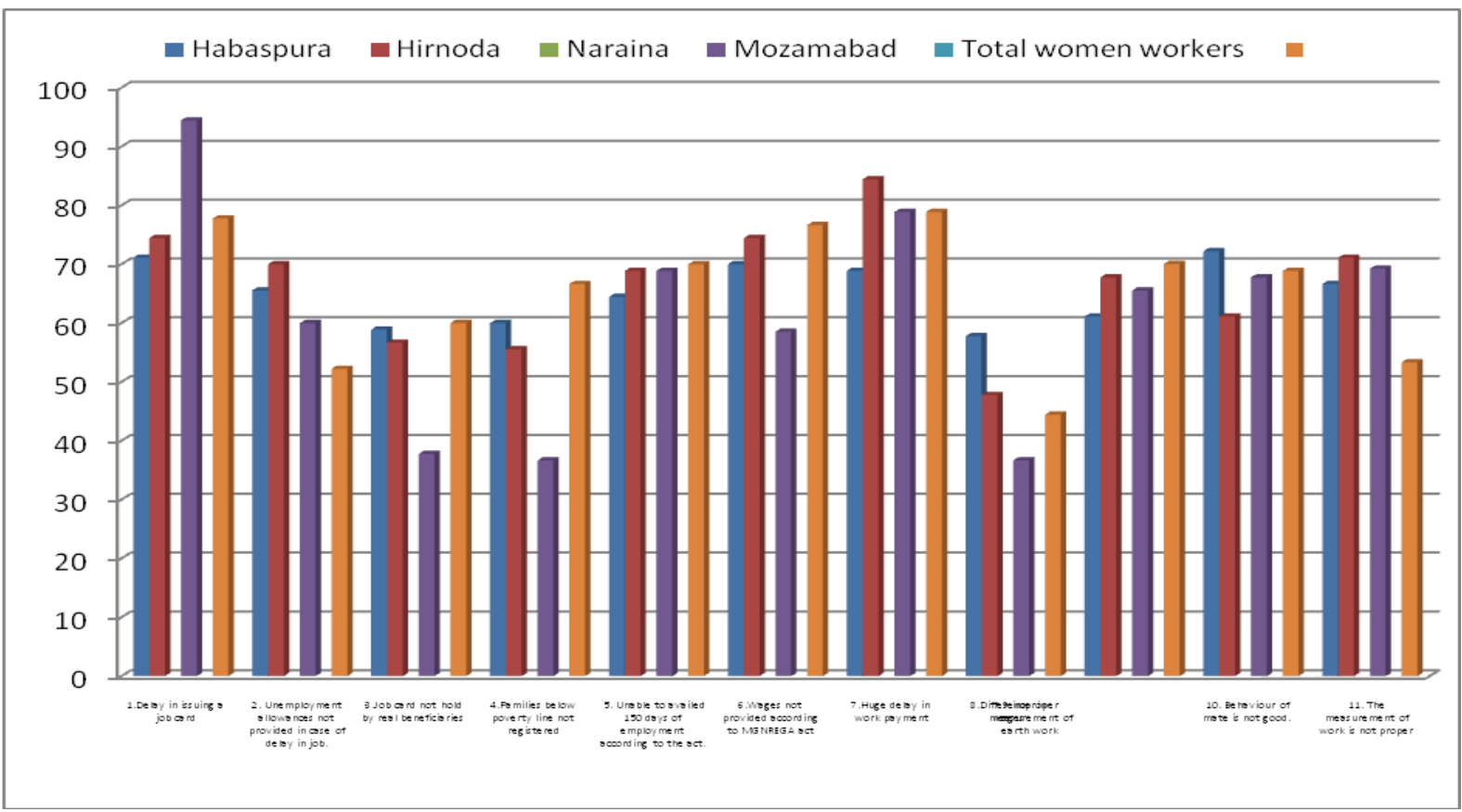

Least important problems faced by the workers were "difference in wages "(46.94 MPS) and "job card not hold by real beneficiaries" (53.34 MPS) followed by "families below poverty line not registered" (54.74 MPS). Under MGNREGA programme equal wages are paid to men and women that 'why workers did not face such problems.

The findings of this study support the findings of Bishnoi at el. (2012), Tiwari and Upadhyay (2012), Sarkar at el. (2011). 


\section{Worksite}

Data reveal that the most important problems faced by the women workers were "Lack of safe drinking water" (73.38 MPS) "and "No shade during rest period" (72.77MPS). May be because the MGNREGA works are taken up during slack season i.e. summers when water requirement is high and there is a scarcity of water in rural areas. Problems like "No extra facilities are given to women" (53.20 MPS) "Ex- gratia payment not given after injury" (53.33 MPS) were least important for women because this progarmme do not give permanent employment to the workers so they do not accept such facilities.

The findings of this study support the findings of Tiwari and Upadhyay (2012), Anand (2008), Patel (2008) and Dreze et al., (2007).

It can be concluded from the present study most important problems faced by women workers: "Children left uncared" (personal and family), "Delay in issuing a job card" (operational) and "Lack of drinking water facility" at worksite.

Whereas least important problems faced by women workers: "Non-cooperation from family members" (personal and family), "Difference in wages "(operational) and "No extra facilities are given to women" at worksite.

\section{References}

Anand, V. 2008. Cited in Panchayati Raj Update by Mohanty B Mahatma Gandhi National
Rural Employment Guarantee Act: A Women Programme. www.knowledge.nrega.net.

Bishnoi, S., Rampal, V.K. and Meena, H.R. 2015. Constraints experienced by women work force in MNREGA in Punjab and Rajasthan, India. Indian Journal of Agricultural Research.Volume:49, Issue: 3 pp 286-289.

Dreze J 2006. "National Employment Guarantee Inaction", the Hindu, 12.September. From <http:

//www.hindu.com/2006/09/12/stories/2006 091205181000.htm.> (Retrieved on 12/3/ 2011).

Garg S 2008. Economic Impact of National Rural Employment Guarantee Programme on Women. M.Sc.Thesis, Unpublished. Mahrana Pratap University of Agriculture and Technology, Udaipur.

Patel, S.S. 2008. A study on opinion of the respondent about the National Rural Employment Guarantee Scheme in Farukhabad district (U.P.). Unpublished M.Sc. (Ag.) Thesis, Department of Agriculture Extension, CSAUA\&T, Nawabganj, Kanpur, Uttar Pradesh.

Sarkar, P., Kumar, J. and Supriya, 2011. Impact of MGNREGA on reducing rural poverty and improving socio-economic status of rural poor: A study in Burdwan District of West Bengal. Agricultural economics research review Vol. 24 pp 437-448.

Tiwari, N. and Upadhyay, R. 2012. Constraints Faced by the Women Beneficiaries under Mahatma Gandhi National Rural Employment Guarantee Act (MGNREGA). Department of Home Science Extension and Communication Management, College of Home Science, MPUAT, Udaipur 313 001, Rajasthan, India. 6(2): 99-102.

\section{How to cite this article:}

Annu Devi Gora, Madhuri Joshi and Radhika Tanwer. 2017. Problems Perceived by the Women Workers under MGNREGA in Jaipur District of Rajasthan, India. Int.J.Curr.Microbiol.App.Sci. 6(8): 3591-3596. doi: https://doi.org/10.20546/ijcmas.2017.608.431 